\title{
Ocena petycji w sprawie zmiany ustawy o ujawnianiu informacji o dokumentach organów bezpieczeństwa państwa z lat 1944-1990 oraz treści tych dokumentów ${ }^{1}$
}

\begin{abstract}
Evaluation of the petition regarding the amendment of the act on disclosure of information on documents of state security autorities from 1944-1990 and the content of these documents: The petition contains a proposal to supplement the subjective catalogue of the lustration act in connection with the entry into force of the Act on the Metropolitan Union in the Śląskie Voivodeship, establishing the authorities forming the organizational structure of the union. The legal nature and scope of tasks of the metropolitan union means that in the doctrine this relationship was called a new institution of a local self-government. Pursuant to the provisions of the lustration act, individuals holding positions in local self-government authorities are subject to the provisions of that act, therefore they should be subject to its obligations. The lack of explicit specification of these individuals in the lustration act raises doubts as to the intentions of the lawgiver. An appropriate amendment to the act would clearly determine the lustration obligation of individuals sitting in the authorities of a metropolitan union.
\end{abstract}

Keywords: lustration | petition | local self-government

Słowa kluczowe: lustracja | petycja | samorząd terytorialny

Doktorant na Wydziale Prawa Kanonicznego UKSW, ekspert ds. oceny skutków regulacji BAS; wioleta.wasil@sejm.gov.pl.

\section{Treść i cel petycji}

Przedmiotem petycji nr 145-303/17 jest żądanie nowelizacji ustawy z 18 października 2006 r. o ujawnianiu informacji o dokumentach organów bezpieczeństwa państwa z lat 1944-1990 oraz treści tych dokumentów (Dz.U. 2017, poz. 2186;

1 Opinia prawna na temat petycji nr 145-303/17 w sprawie zmiany ustawy $z$ dnia 18 października 2006 r. o ujawnianiu informacji o dokumentach organów bezpieczeństwa państwa $z$ lat 1944-1990 oraz treści tych dokumentów sporządzona 30 stycznia $2018 \mathrm{r}$. na zlecenie przewodniczącego Komisji ds. Petycji; BAS-WAP 4/18. 
dalej: ustawa lustracyjna), w zakresie zobowiązania osób pełniących funkcje członków zarządów, skarbników i sekretarzy w związkach metropolitarnych do składania oświadczeń lustracyjnych. Uzupełnienie katalogu podmiotowego ustawy lustracyjnej (art. 4) jest spowodowane wejściem w życie ustawy z 9 maja 2017 r. o związku metropolitalnym w województwie śląskim (Dz.U. poz. 730; dalej: ustawa metropolitalna), ustanawiającej organy tworzące strukturę organizacyjną związku, piastowane przez osoby, które z racji pełnionej funkcji winny cieszyć się powszechnym zaufaniem obywateli.

Opiniowaną petycję wniosła Fundacja Centrum Analiz dla Rozwoju. Petycji towarzyszy propozycja legislacyjna nowelizacji ustawy lustracyjnej w następującym brzmieniu:

„Ustawa z dnia ... r. o zmianie ustawy o ujawnieniu informacji o dokumentach organów bezpieczeństwa państwa z lat 1944-1990 oraz treści tych dokumentów

Art. 1. W ustawie z dnia 18 października 2006 r. o ujawnianiu informacji o dokumentach organów bezpieczeństwa $z$ lat 1994-1990 oraz treści tych dokumentów (Dz. U. z 2016 r. poz. 1721, 2260, 2261 i 1948 oraz z 2017 r. poz. 1530, 1600 i 1909) wprowadza się następujące zmiany:

1) w art. 4:

a) pkt 17 otrzymuje brzmienie:

„17) organ i członek organu jednostki samorządu terytorialnego, organu związku jednostek samorządu terytorialnego, organu jednostki pomocniczej jednostki samorządu terytorialnego, organu jednostki pomocniczej jednostki samorządu terytorialnego, której obowiązek utworzenia wynika z ustawy oraz organu związku metropolitalnego;",

b) pkt 32 otrzymuje brzmienie:

„32) skarbnik województwa, powiatu, gminy lub związku metropolitalnego oraz sekretarz powiatu, gminy lub związku metropolitalnego;";

2) w art. 8 pkt 16 otrzymuje brzmienie:

„16) pkt 17:

a) w stosunku do osoby ubiegającej się o funkcję organu lub członka organu jednostki samorządu terytorialnego, której obowiązek utworzenia wynika z ustawy, pochodzącego z wyborów powszechnych - właściwa komisja wyborcza,

b) w stosunku do osoby ubiegającej się o funkcję organu lub członka organu

c) w stosunku do pozostałych osób - właściwy wojewoda";

3) w art. 22 w ust. 1 pkt 20 kropkę zastępuje się średnikiem i dodaje się pkt 21 w brzmieniu:

„21) organów lub członków organów związku metropolitalnego oraz skarbników i sekretarzy związku metropolitalnego.”.

Art. 2. Osoba pełniąca funkcję organu lub członek organu związku metropolitalnego, sekretarz związku metropolitalnego i skarbnik związku metropolitalnego - który objął funkcję przed dniem wejścia w życie niniejszej ustawy - składają 
oświadczenie, o którym mowa w art. 7 ust. 1 ustawy wymienionej w art. 1 w terminie 3 miesięcy od dnia wejścia w życie niniejszej ustawy. Przepis art. 7 ustawy wymienionej w art. 1 stosuje się odpowiednio.

Art. 3. Ustawa wchodzi w życie po upływie 14 od dnia ogłoszenia”.

\section{Czy petycja mieści się w zakresie zadań i kompetencji adresata petycji (art. 2 ust. 3 ustawy o petycjach)?}

Petycja dotyczy zmiany ustawy przez Sejm. Zgodnie z art. 95 ust. 1 Konstytucji RP władzę ustawodawczą w Rzeczypospolitej Polskiej sprawują Sejm i Senat. Natomiast stosownie do art. 118 ust. 1 Konstytucji inicjatywa ustawodawcza przysługuje m.in. posłom. Artykuł 32 ust. 2 regulaminu Sejmu, w związku z art. 112 Konstytucji, precyzuje, że poselskie projekty ustaw mogą być wnoszone przez komisje sejmowe lub grupę co najmniej 15 posłów podpisujących projekt.

Uwzględniając powyższe, należy uznać, że petycja mieści się w zakresie zadań i kompetencji Sejmu.

\section{Wymogi formalne (art. 4 ust. 1 i 2 ustawy o petycjach)}

Petycja spełnia wymogi formalne określone w art. 4 ust. 1 i 2 ustawy o petycjach.

\section{Kwestie, które ekspert uznaje za istotne w związku z petycją}

Ustawa lustracyjna w art. 4 zawiera zamknięty katalog osób pełniących funkcje publiczne, zobowiązanych do składania oświadczeń lustracyjnych. Wymienia wśród nich: organ i członka organu jednostki samorządu terytorialnego (dalej: j.s.t), organ związku j.s.t. oraz organ jednostki pomocniczej j.s.t. (art. 4 ust. 17 ustawy lustracyjnej). Z dniem 7 kwietnia 2017 r. zaczęła obowiązywać ustawa metropolitalna, ustanawiająca nową instytucję prawną, jaką jest związek metropolitalny (obecnie funkcjonuje jeden związek metropolitalny - Górnośląsko-Zagłębiowska Metropolia). Ustawodawca definiuje związek metropolitalny jako zrzeszenie gmin województwa śląskiego, charakteryzujących się istnieniem silnych powiązań funkcjonalnych oraz zaawansowaniem procesów urbanizacyjnych, położonych w obszarze spójnym pod względem przestrzennym, które zamieszkuje 2000000 mieszkańców (art. 1 ust. 1 ustawy metropolitalnej). Związek metropolitalny ma osobowość prawną, wykonuje zadania publiczne w imieniu własnym i na własną odpowiedzialność. W literaturze przedmiotu dostrzeżono wiele podobieństw pomiędzy konstrukcją związku metropolitalnego i związku 
komunalnego ${ }^{2}$, które uprawniały do twierdzenia, że związek metropolitalny mógł być klasyfikowany jako szczególny rodzaj związku jednostek samorządu terytorialnego. Przedstawiciele odmiennego poglądu doktryny, uwzględniając regulacje zawarte w ustawie metropolitalnej, utrzymują, że twierdzenie to straciło aktualność ${ }^{3}$. Związek metropolitalny zatem nie jest związkiem komunalnym w rozumieniu ustaw samorządowych. Przytoczeni autorzy podtrzymują, że niedopuszczalne jest odpowiednie stosowanie przepisów o związkach: międzygminnych, powiatowych czy powiatowo-gminnych w stosunku do związku metropolitalnego. Dokonując interpretacji charakteru prawnego związku, stwierdzili, że powstały twór należy uznać jako nową instytucję samorządu terytorialnego. O powiązaniu związku metropolitalnego z jednostkami samorządu terytorialnego świadczy także zakres zadań powierzonych mu przez ustawodawcę. Zgodnie z art. 12 ustawy metropolitalnej oprócz zadań własnych, które ówcześnie były zastrzeżone dla jednostek samorządu terytorialnego ${ }^{4}$, może on realizować lub koordynować zadania publiczne należące do zakresu działań tych jednostek oraz administracji rządowej. Na podstawie przytoczonych argumentów nie można wykluczyć, że związek metropolitalny mieści się w kategorii jednostki samorządu terytorialnego. Mając powyższe na względzie, umieszczenie organu związku metropolitalnego w katalogu (art. 4 ustawy lustracyjnej) podmiotów zobowiązanych do składania oświadczenia lustracyjnego mogłoby skutecznie ograniczyć stan niepewności prawnej, zwiększyć spójność prawa oraz wypełnić lukę prawną, jaka wystąpiła w ustawie lustracyjnej po wprowadzaniu ustawy metropolitalnej.

Nie można jednak wykluczyć, że w stosunku do organów związku metropolitalnego ustawodawca nie przewidział takiego obowiązku. W art. 26 ustawy metropolitalnej w stosunku do zgromadzenia związku metropolitalnego, w zakresie nieregulowanym przez ustawę, wskazał na odpowiednie stosowanie przepisów dotyczących sejmiku wojewódzkiego. Zgodnie z art. 15 ust. 1 ustawy z 5 czerwca 1998 r. o samorządzie województwa (Dz.U. 2017, poz. 2096) sejmik jest jednym z organów samorządu. Jak stanowi art. 4 ust. 17 ustawy lustracyjnej, organ i członek organu jednostki terytorialnej zobligowany jest do składania oświadczenia lustracyjnego. W stosunku do członków zarządu związku metropolitalnego,

2 T. Bąkowski [w:] Ustawa o związkach metropolitalnych. Komentarz, red. T. Bąkowski, Warszawa 2016, s. 17-18.

3 B. Dolnicki, R. Marchaj, Związek metropolitalny w województwie śląskim, „Samorząd Terytorialny" 2017, nr 7-8, s. 15-16.

4 Takie jak: kształtowanie ładu przestrzennego, rozwój społeczny i gospodarczy obszaru związku metropolitalnego, planowanie, koordynacja, integracja oraz rozwój publicznego transportu zbiorowego, w tym transportu drogowego, kolejowego oraz innego transportu szynowego, a także zrównoważona mobilność miejska, metropolitalne przewozy pasażerskie, współdziałanie w ustalaniu przebiegu dróg krajowych i wojewódzkich na obszarze związku metropolitalnego, promocja związku metropolitalnego i jego obszaru. 
a także skarbnika i sekretarza art. 39 ustawy metropolitalnej w zakresie nieuregulowanym ustawą nakazuje odpowiednio stosować przepisy dotyczące zarządu województwa, członków zarządu województwa, skarbnika województwa oraz sekretarza województwa. Zgodnie z art. 15 ust. 2 ustawy o samorządzie województwa zarząd województwa jest organem województwa jako jednostki samorządu terytorialnego i podlega dyspozycji art. 4 ust 17 ustawy lustracyjnej. Podobnie jak skarbnik województwa (sekretarz województwa nie występuje w przepisie), który zgodnie z art. 4 ust. 32 ustawy lustracyjnej także podlega powyższemu zobowiązaniu. Przedstawiona wykładnia przepisów budzi wątpliwości interpretacyjne, spowodowane nakazem odpowiedniego (a nie wprost) stosowania przepisów ustawy lustracyjnej.

Sformułowanie „odpowiednio” w technice prawodawczej stosowane jest jako pośrednik bądź odnośnik (w zależności od rodzaju przepisu) między różnymi aktami prawnymi czy przepisami tego samego aktu. Za wyrokiem Sądu Najwyższego z 15 lutego 2008 r., sygn. akt I CSK 357/07, uznać należy, że: [w] literaturze i orzecznictwie nie budzi wątpliwości, że odpowiednie stosowanie przepisów prawa oznacza bądź stosowanie odnośnych przepisów bez żadnych zmian do innego zakresu odniesienia, badź stosowanie ich z pewnymi zmianami, bądź też niestosowanie tych przepisów do innego zakresu odniesienia. Dyrektywa odpowiedniego stosowania przepisów, co do zasady, ułatwia dokonywanie wykładni przepisów oraz zapobiega inflacji prawa powodowanej tworzeniem nieustająco nowych przepisów. Jakkolwiek z racji specyfiki omawianej materii nie można wykluczyć, że odpowiednie stosowanie przepisów może wpływać na zmniejszenie stopnia pewności prawa oraz powodować trudności w prawidłowym stosowaniu przepisów.

Zgodnie z preambułą do ustawy lustracyjnej zasadność obowiązku składania oświadczeń lustracyjnych przez osoby urodzone przed dniem 1 sierpnia 1972 r. (art. 7 ust. 1), pełniące obecnie ważne funkcje publiczne, przejawia się w dbałości o transparentność zachowań oraz gwarancje prawości osób sprawujących te stanowiska. Przepisy ustawy lustracyjnej w stosunku do osób, które złożyły niezgodne z prawdą oświadczenia lustracyjne (bądź w ogóle ich nie złożyły), przewidują istotne konsekwencje, w tym także natury karnej (np. art. 21e, art. 29, art. 57). Ponadto w stosunku do osoby poddawanej postępowaniu lustracyjnemu zastosowanie znajdują przepisy dotyczące oskarżonego w postępowaniu karnym, natomiast w kwestiach nieuregulowanych ustawą lustracyjną odpowiednio stosuje się przepisy procedury karnej. Mając na względzie prawnokarny charakter niektórych postanowień ustawy lustracyjnej, zawarte w niej przepisy oraz wszelkie inne akty prawne odsyłające do niej, powinny być stanowione poprawnie, precyzyjnie i jasno. Cechy te odpowiadają zasadzie określoności prawa, która mieści się w nakazie przestrzegania reguł przyzwoitej legislacji. Nakaz ten jest jedną z form realizacji obowiązku państwa, jakim jest zapewnianie bezpieczeństwa obywatelowi. Powinność ta opiera się na wymogu pewności stanowionego 
prawa, które zapewni jednostce bezpieczeństwo prawne. Oznacza to, że jednostka ma możliwość określenia konsekwencji poszczególnych zachowań i zdarzeń na gruncie obowiązującego w danym momencie systemu, którego prawodawca bezwzględnie nie zmieni. U podstaw tego obowiązku leży zasada zaufania obywateli do państwa i stanowionego przez nie prawa, zajmująca nadrzędne miejsce w systemie wartości składających się na pojęcie demokratycznego państwa prawnego ${ }^{5}$. Istota tej zasady ujęta została w wyroku Trybunału Konstytucyjnego z 15 września 1998 r., sygn. akt K 10/98: wyraża się w takim stanowieniu $i$ stosowaniu prawa, by nie stawało się ono swoista pułapka dla obywatela $i$ aby mógł on układać swoje sprawy w zaufaniu, iż nie naraża się na prawne skutki, których nie mógł przewidzieć $w$ momencie podejmowania decyzji i działań, oraz w przekonaniu, iż jego działania podejmowane zgodnie z obowiązujacym prawem będa także w przyszłości uznawane przez porządek prawny. Podejmowane przez ustawodawce nowe unormowania nie moga zaskakiwać ich adresatów, którzy powinni mieć czas na dostosowanie się do zmienionych regulacji i spokojne podjęcie decyzji co do dalszego postępowania. Zasada zaufania obywateli do państwa i stanowionego przez nie prawa wchodzi w skład szerszej zasady wyrażonej w art. 2 Konstytucji, tj. zasady demokratycznego państwa prawa.

Tworzenie przepisów w zgodzie z zasadami demokratycznego państwa prawa oraz techniki legislacyjnej umożliwia realizację gwarancyjnej funkcji prawa karnego. Dochowanie wierności względom gwarancyjnym prawa karnego uniemożliwia samowolę w procesie stanowienia i stosowania prawa, a więc zabezpiecza wolności i prawa człowieka przed arbitralną ingerencją aparatu przymusu państwowego ${ }^{6}$. Postulat ten jest szczególnie doniosły w przypadku przepisów o charakterze prawnokarnym, które pociągają za sobą konkretne sankcje karne, jak jest to w przypadku ustawy lustracyjnej. Funkcja gwarancyjna prawa karnego ma swoje umocowanie w art. 42 ust. 1 Konstytucji, zgodnie z którym odpowiedzialności karnej podlega tylko ten, kto dopuścił się czynu zabronionego pod groźbą kary przez ustawę, obowiązującą w chwili jego popełnienia. W doktrynie i orzecznictwie wskazuje się, że art. 42 ust. 1 Konstytucji zawiera w sobie dwie podstawowe, fundamentalne dla prawa karnego zasady: nullum crimen sine lege i nulla poena sine lege, stanowiące aksjologiczne podstawy funkcjonowania odpowiedzialności karnej. Z uwagi na przedmiot omawianej materii, kluczową pozostaje zasada nullum crimen sine lege, zgodnie z którą czyn zabroniony pod groźbą kary musi być określony i przewidziany w ustawie obowiązującej w czasie jego popełnienia ${ }^{7}$. Prawnokarny charakter przepisów ustawy lustracyjnej rodzi konieczność

5 G. Koksanowicz, Zasada określoności przepisów w procesie stanowienia prawa, „Studia Iuridica Lublinensia" 2014, nr 22, s. 472-475.

6 J. Warylewski, Prawo karne. Część ogólna, Warszawa 2004, s. 61.

7 T. Sroka [w:] Konstytucja RP. Komentarz, t. I, Art. 1-86, red. M. Safian, L. Bosek, Warszawa 2016, s. 1027-1028. 
dochowania warunku jednoznaczności stanowionych przepisów, w taki sposób, aby proces odtwarzania zawartych w nich norm prawnych nie doprowadzał do wielu rozwiązań interpretacyjnych. Wymóg ten wyraża się w podstawowej zasadzie prawa karnego nullum crimen sine lege certa, która zastrzega precyzyjne ujmowanie znamion typu czynu zabronionego. Jest to naturalna konsekwencja wymagań stawianych każdej racjonalnie sformułowanej normie prawnej ${ }^{8}$.

\section{Wnioski}

Wejście w życie ustawy metropolitalnej zrodziło wątpliwości dotyczące obowiązku składania oświadczeń lustracyjnych przez osoby zajmujące stanowiska w organach związku metropolitalnego. Charakter prawny i zakres zadań związku metropolitalnego sprawia, że w doktrynie związek ten nazwany został nową instytucją samorządu terytorialnego. Zgodnie zaś z przepisami ustawy lustracyjnej piastuni organów samorządu terytorialnego podlegają dyspozycji ustawy lustracyjnej. W związku z tym wydawać by się mogło, że osoby piastujące organy związku metropolitalnego winny podlegać obowiązkowi wynikającemu z ustawy lustracyjnej. Ustawodawca, wprowadzając do porządku prawnego instytucję związku metropolitalnego, nie dokonał jednak nowelizacji ustawy lustracyjnej i nie dodał do zawartego w tej ustawie katalogu podmiotów objętych jej dyspozycją osób zasiadających w organach związku metropolitalnego. Brak wyszczególnienia wprost tych osób w ustawie lustracyjnej rodzi wątpliwości co do intencji ustawodawcy. Uznać należy zatem, że odpowiednia nowelizacja ustawy lustracyjnej jednoznacznie przesądziłaby o obowiązku lustracyjnym osób zasiadających w organach związku metropolitalnego.

\section{Bibliografia}

Bąkowski T. [w:] Ustawa o związkach metropolitalnych. Komentarz, red. T. Bąkowski, Warszawa 2016.

Dolnicki B., Marchaj R., Związek metropolitalny w województwie śląskim, „Samorząd Terytorialny" 2017, nr 7-8.

Koksanowicz G., Zasada określoności przepisów w procesie stanowienia prawa, „Studia Iuridica Lublinensia" 2014, nr 22, https://doi.org/10.17951/sil.2014.22.0.471.

Phol Ł. [w:] Kodeks karny. Komentarz, Warszawa 2015.

Sroka T. [w:] Konstytucja RP. Komentarz, t. I, Art. 1-86, red. M. Safian, L. Bosek, Warszawa 2016.

Warylewski J., Prawo karne. Część ogólna, Warszawa 2004.

8 Ł. Phol [w:] Kodeks karny. Komentarz, Warszawa 2015, s. 34-35. 